Le Lait (1984), 64, 1-15

\title{
Acid curd cheese by MMV method with Lactobacillus acidophilus
}

\author{
by \\ J. KOROLCZUK* and Dorota GRZELAK**
}

\section{S u m m a ry}

UF retentates from milk and whey containing respectively $22 \%$ and $14 \%$ dry matter, $14 \%$ and $6.6 \%$ protein, $4.7 \%$ and $4.8 \%$ lactose, $1.7 \%$ and $0.9 \%$ ashes, from the initial $\mathrm{pH} 6.3-6.8$ were acidified by Lactobacillus acidophilus to $\mathrm{pH}$ 3.6-3.8 i.e. a lactic acid content 3-3.5 \%. Pasteurized, acidified milk or whey retentates (32\% or $35 \%$ ) were mixed with $63 \%$ or $60 \%$ pasteurized non-acidifield milk retentate and with $5 \%$ butter starter. The acid curd cheese contained respectively from milk and whey: $21 \%$ or $18 \%$ dry matter, $13 \%$ or $11 \%$ protein, $3.8 \%$ or $3.7 \%$ lactose, $1.6 \%$ or $1.4 \%$ ash, 1.3 lactic acid and had $\mathrm{pH}$ 4.7.

Pasteurized milk or whey retentates contained $10^{5}$ C.F.U./ml as mesophilic flora. E. coli and Enterococci were absent in $0.1 \mathrm{ml}$ or $0.01 / \mathrm{ml}$. Yeasts number per $\mathrm{ml}$ was $10^{1}$ or $10^{2}$ and molds $10^{1}$. Pasteuzed, acidified retentates from milk and whey have $10^{4}$ C.F.U. $/ \mathrm{ml}$. E. coli and Enterococci were absent in $0.1 / \mathrm{ml}$. Yeasts and molds number was $10^{\circ} / \mathrm{ml}$.

During 21 days of storage at $10^{\circ} \mathrm{C}$, the C.F.U./ml increased from $10^{7}-10^{8}$ to $10^{9}-10^{10}$. E. coli and Enterococci were absent in $0.1 \mathrm{ml}$. Yeasts and molds number per $\mathrm{ml}$ increased from $10^{0}$ to $10^{1}-10^{3}$. Organoleptic quality was found acceptable for 10 days of storage the cheese at $10^{\circ} \mathrm{C}$.

Key words: Acid curd cheese, L. acidophilus, ultrafiltration, whey protein. Abbrevieted tittle: Acid curd cheese.

* Till 30 Sept. 1984 : Laboratoire de Recherches de Technologie Laitière (I.N.R.A.), 65, rue de Saint-Brieuc - 35042 Rennes cedex then as**.

** Institute of Dairy Industry, 66/68 Hoza Str, 00-682 Warsaw, Poland. 


\section{Rés u m é}

Des rétentats d'ultrafiltration de lait et de lactosérum contenaint respectivement $22 \%$ et $14 \%$ de matière sèche, $14 \%$ et $6,6 \%$ MAT, $4,7 \%$ et $4,8 \%$ de lactose, $1,7 \%$ et $0,9 \%$ de cendres, d'un $\mathrm{pH}$ initial 6,3-6,8 ont été acidifiés par Lactobacillus acidophilus jusqu'au pH 3,6-3,8 correspondant à une teneur en acide lactique 3-3,5\%. Le rétentat pasteurisé, acidifié de lait (32\%) ou de lactosérum (35\%) étaient mélangés dans la proportion respective de $63 \%$ et $60 \%$ de rétentat du lait pasteurisé non-acidifié et avec $5 \%$ de ferments du beurre. Le fromage de caillé acide contenait respectivement pour celui obtenu à partir de lait et celui obtenu à partir de lactosérum $21 \%$ et $18 \%$ de matière sèche, $13 \%$ et $11 \%$ de MAT, 3,8\% et 3,7\% de lactose, $1,6 \%$ et $1,4 \%$ de cendres et $1,3 \%$ d'acide lactique et avait un $\mathrm{pH} 4,7$.

Les rétentats pasteurisés de lait et de lactosérum avaient une flore totale mésophile de $10^{5}$ germes par $\mathrm{ml}$. E. coli et Enterococcus étaient absents dans $0,1 \mathrm{ml}$ ou $0,01 \mathrm{ml}$. Le nombre de levures atteignait $10^{1}-10^{2} / \mathrm{ml}$ et les moisissures $10^{1} / \mathrm{ml}$. Les rétentats pasteurisés acidifiés du lait et du lactosérum contenaient une flore totale mésophile de $10^{4}$ germes par $m l \mathrm{E}$. coli et Enterococcus étaient absents dans $0,1 \mathrm{ml}$. Le nombre de levures et de moisissures était de $10^{\circ} / \mathrm{ml}$.

Pendant 21 jours de stockage à $10^{\circ} \mathrm{C}$, la flore totale mésophile augmentait de $10^{7}-10^{8} / \mathrm{ml}$ à $10^{9}-10^{10} / \mathrm{ml}$. E. coli et Enterococcus étaient absents dans $0.1 \mathrm{ml}$. Le nombre de levures et de moisissures augmentait de $10^{\circ}$ à $10^{1}-10^{3} / \mathrm{ml}$. La qualité organoleptique des fromages était acceptable pendant les dix premiers jours de stokage à $10^{\circ} \mathrm{C}$.

Mots clés : Fromage de caillé acide, L. acidophilus, ultrafiltration.

Titre abrégé : Fromage de caillé acide.

\section{INTRODUCTION}

Application of ultrafiltration for preparation of cheese by the method called MMV (Maubois and al., 1969) increases the recovery of milk protein from $79-83 \%$ to $93-95 \%$ (Maubois and Mocquot, 1971) and the yield of cheese by $15-20 \%$ (Maubois and Mahaut, 1974). Preparation of acid curd cheese type quarg by this method has been described in numerous articles (Brulé and al., 1975; Puhan and Gallmann, 1981 ; Friis, 1981 ; Gungerich, 1981 ; Mahaut and al., 1982 ; Mann, 1982 a, b; Maubois and Brulé, 1982 ; Moldovan and al., 1982). Direct ultrafiltration at normal $\mathrm{pH}$ enables to retain whey proteins and the colloildal calcium, normaly being lost with the quarg whey (Brulé and al., 1974). The quarg obtained through this method could be of good quality (Gungerich, 1981; Moldovan and al., 1982) but 
sometimes acidic taste is detected (Brulé and al., 1975). To reduce calcium retention, the $\mathrm{pH}$ of milk, before ultrafiltration takes place, has to be slightly decreased (Brulé and al., 1974; Friis, 1981 ; Puhan and Gallmann, 1981) or even, as described by Stenne, 1973 and Mahaut and al., 1982 lowered until pH 4.5-4.7 when UF equipments authorize treatment of highly viscous dairy products. Whey proteins can also be separated from the whey by ultrafiltration and added to the cheese milk or quarg obtained by traditional method (Knupfer, 1982 ; Stenne, 1976).

Traditional technology of acid curd cheese requires acidification of milk to $\mathrm{pH} 4.6$ to enable the separation of casein curd by centrifugation or decantation and filtration. The acidification by mesophilic lactic acid bacteria lasts for 6-20 hours at $25-30^{\circ} \mathrm{C}$. Because of parallel multiplication of other microorganisms, the acid type curd is generally contaminated by E. coli, Staphylococci, Pseudomonas, Enterococci, Klebsiella, anaerobic spores, hemolytic bacteria and other pathogenic microorganisms (Maleszewski and al., 1976 ; Burzynska, 1980 ; Feder, 1981 ; Maciejska-Roczan and Burzynska, 1981).

The application of higher temperature and longer time for milk pasteurization results with higher retention of milk proteins (Korolczuk and al., 1971, 1975; Strmiska, 1980; Dolle, 1981) higher nutritive value (Korolczuk and al., 1975) and improved microbiological quality (Kroger, 1979; Strmiska, 1980; Dolle, 1981) but gives softer texture because of higher retention of water (Daniewski, 1973).

Thermization of acid curd cheese (Snoeren, 1980 ; Strmiska, 1980; Dolle, 1981) improves very much microbiological quality but requires special hydrocolloids to prevent excessive expulsion of whey.

Another method is based on pasteurization of milk acidified to $\mathrm{pH} 3.5$ or below with thermophilic starter, and preparation of acid curd cheese by mixing $1 / 3$ of acidified milk with $2 / 3$ of nonacidified pasteurized milk and with $5 \%$ of mesophilic starter (Korolczuk and al., 1983).

In the case of Poland, where annual per capita consumption of acid curd cheese, called tvarog is of the range $9.5 \mathrm{~kg}$, while rennet type cheeses only $2.5-2.6 \mathrm{~kg}$ (FIL, 1981) the implantation of MMV method for production of this type of cheese would be important from economical but also from nutritional point of view. The initial trials however were not very successful, mainly because of low microbiological quality of raw milk.

The aim of this work was to use thermophilic starter ( $L$. acidophilus) for preparation of acid curd cheese (Korolczuk and al., 1983) from milk and whey protein retentates prepared, as described by Maubois and Mocquot (1971), to obtain quarg type cheese enriched in whey proteins and calcium and of higher microbiological and keeping quality. 


\section{MATERIALS AND METHODS}

Pooled skimmilk and skimmed semi-hard cheese whey obtained with a rennet like microbial enzyme-fromase (Rapidase Co., France) were used for the preparation of milk and whey retentates.

Amicon (U.S.A.) hollow-fiber, $3 \times 0.9 \mathrm{~m}^{2}$ UF module was used for ultrafiltration. 100 litre of milk or 150 litre of whey pasteurized at $65^{\circ} \mathrm{C}$ for 20 minutes were ultrafiltrated to remove about $80 \%$ of permeate from milk and $90 \%$ from the whey (fig. 1). The initial
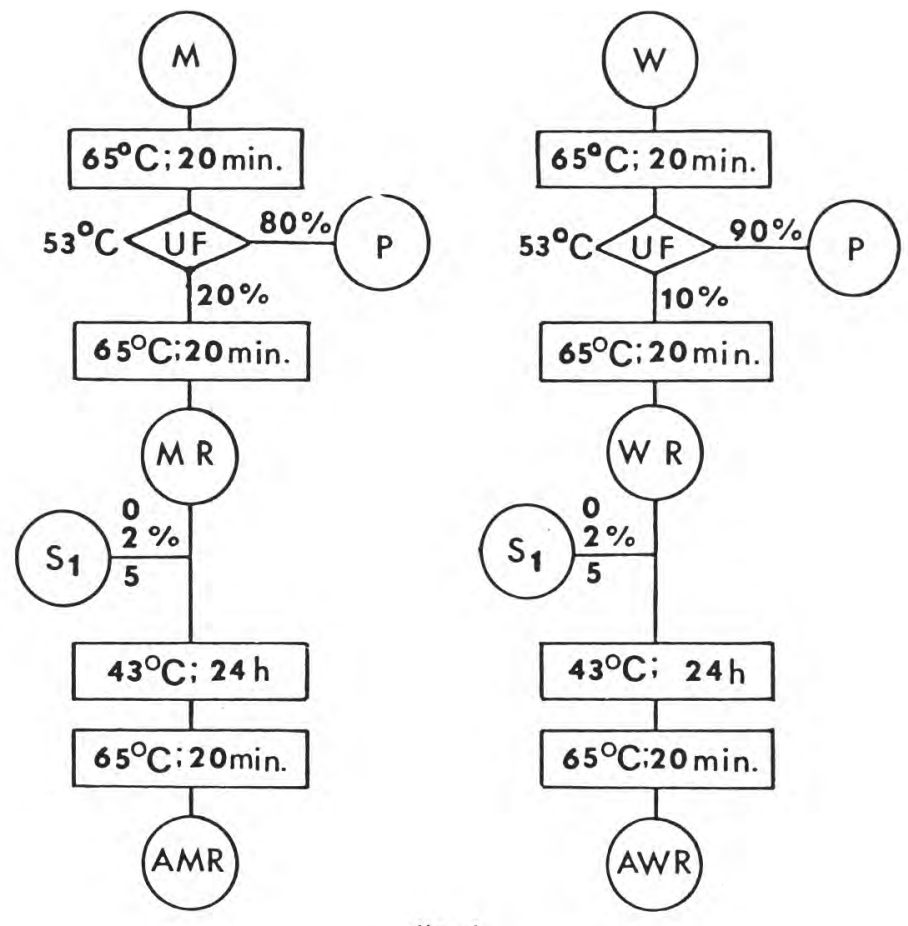

fig. 1

Schéma of preparation of retentates and acidified retentates from skim milk and whey. M-milk, W-whey, UF-ultrafiltration, MR-milk retentate, WR-whey retentate, P-permeate, $\mathrm{S}_{1}-L$. acidophilus starter, AMR-acidified milk retentate, AWR-acidified whey retentate.

Schéma du procédé de préparation des rétentats de lait écrémé et de lactosérum : M.-lait, W-lactosérum, UF-ultrafiltration, MR-rétentat de lait, WR-rétentat de lactosérum, P-perméat, $S_{1}$-levain de L. acidophilus, $A M R$-rétentat acidifié du lait, AWR-rétentat acidifié du lactosérum. 
ultrafiltration rate was about $50 \mathrm{l} / \mathrm{m}^{2} \cdot \mathrm{h}$ and final about $10 \mathrm{l} / \mathrm{m}^{2} \cdot \mathrm{h}$. The inlet/outlet pressure was 1.8-2.0 bar/0.8-1.0 bar. The recirculation rate was about $2 \mathrm{~m}^{3} / \mathrm{h}$. The temperature was maintened at the level $53 \pm 2^{\circ} \mathrm{C}$. Pasteurized $\left(65^{\circ} \mathrm{C} ; 20 \mathrm{~min}\right)$ retentates were inoculated with 0,2 or $5 \%$ of starter of L. acidophilus 1T (from the collection of Agricultural University in Warsaw). The starter was prepared one day before, on skim milk heated at $95^{\circ} \mathrm{C}$ for $30 \mathrm{~min}$, fermented to the $\mathrm{pH} 4.5-4.3$ at $43^{\circ} \mathrm{C}$ and stored overnight at $5^{\circ} \mathrm{C}$.

For preparation of quargs, the acidified milk retentates (AMR) or acidified whey retentates (AWR) were prepared by inoculation of retentates with $5 \%$ of L.acidophilus starter $\left(\mathrm{S}_{1}\right)$ and the incubation for $24 \mathrm{~h}$ at $43^{\circ} \mathrm{C}$. Acidified retentates to $\mathrm{pH}$ 3.5-3.7 were pasteurized $\left.65^{\circ} \mathrm{C}, 20 \mathrm{~min}\right)$. Quargs were prepared by mixing the milk retentate $(60-63 \%)$ with $5 \%$ of butter starter (Streptococcus lactis Str. cremoris, Str. diacetylactis), added for developing the flavour and for increasing the number of viable lactic acid bacteria, and with $32 \%$ of AMR or $35 \%$ of AWR. The quargs samples, closed in glass jars $(250 \mathrm{~g})$ were kept for 21 days at $10 \pm 2^{\circ} \mathrm{C}$ (fig. 2).

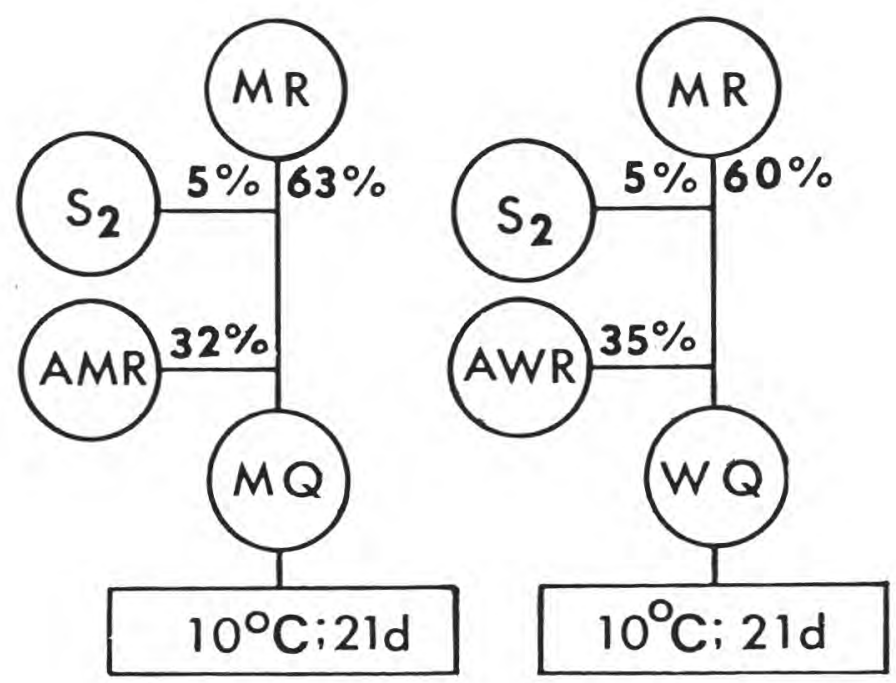

fig. 2

Schema of preparation of quargs from milk retentate (MR), acidified milk retentate (AMR), acidified whey retentate (AWR) and butter starter $\left(\mathrm{S}_{2}\right)$. MQ-milk quarg, WQ-whey protein enriched quarg.

Schéma du procédé de préparation de fromage frais type quarg à partir de : rétentat de lait $(M R)$, rétentat acidifié de lait $(A M R)$, rétentat acidifié de lactosérum $(A W R)$ et de ferments de beurre $\left(S_{2}\right)$. MQ-quarg à base de lait, WQ-quarg enrichi en protéines de lactosérum. 
The $\mathrm{pH}$ of retentates and quargs was determined by means of pH-meter type PHM-64 (Radiometer, Denmark). The titrable acidity was determined using a titrator type TTT-60 (Radiometer, Denmark) and expressed in percentage of lactic acid. Nitrogen was determined by Kjeldahl method using a Kjel-Foss Automatic apparatus (A/S N. Foss Electric, Denmark). Moisture content was determined at $102^{\circ} \mathrm{C}$ for 5 hours and ash at $550^{\circ} \mathrm{C}$ (AOAC, 1975), lactose by Bertrand method (FIL-IDF, 1974 a). Microbiological analysis and sensory evaluation were carried out using standard methods (FIL-IDF, $1971 \mathrm{a}$, b ; 1974 b; $1980 ; 1981$ a).

\section{RESULTS AND DISCUSSION}

During ultrafiltration $\mathrm{pH}$ of milk retentate increased slighty (about 0.2 ) probably because of increased calcium concentration and increased proportion of calcium to soluble anions, as the major part of soluble anions passed through the membrane with the permate, while the major part of calcium was retained with casein.

The level of concentation, about 5 times for the milk and about 10 times for the whey was practically maximal for the hollow fiber type of membranes we used. The viscosity of retentates even at $53^{\circ} \mathrm{C}$ became to high to continue the process. For the whey, though the protein concentration was rather low (below $7 \%$ ) but the viscosity rose too high, probable because of thermal denaturation by $3-4$ hours lasting heating at $53^{\circ} \mathrm{C}$.

Acidification of milk or whey retentates (fig. 3 and 4 ) by L. acidophilus at $43^{\circ} \mathrm{C}$ enabled to achieve the level of $\mathrm{pH} 3.6-3.8$ and the concentration of lactic acid 3.0-3.5 \%. Non-inoculated retentates were acidified by the residual microflora to the level of about $1 \%$ lactic acid and $\mathrm{pH}$ 4.5-5.0.

If not taking into account the existence of lag phase, for the first 6 hours at least the acidification of retentates followed roughly the kinetics of the first order reaction :

$$
\mathrm{pH}-\mathrm{pH}_{0}-\frac{\mathrm{t}}{\mathrm{t}_{1}}
$$

where : $\mathrm{pH}_{0}$ : initial $\mathrm{pH}$ level, calculated by the least squares method:

$t$ : time of acidification in hours,

$t_{1}$ : time of acidification in hours to decrease $\mathrm{pH}$ by 1 unit or to multiply the $\mathrm{H}^{+}$ions concentration by 10 , calculated by the least squares method.

The value $t_{1}$ depended on the quantity of starter added to the whey or milk retentate. As it is given in fig. 3 and 4 the residual microflora caused the decrease of $\mathrm{pH}$ by 1 unit every 24 hours for 


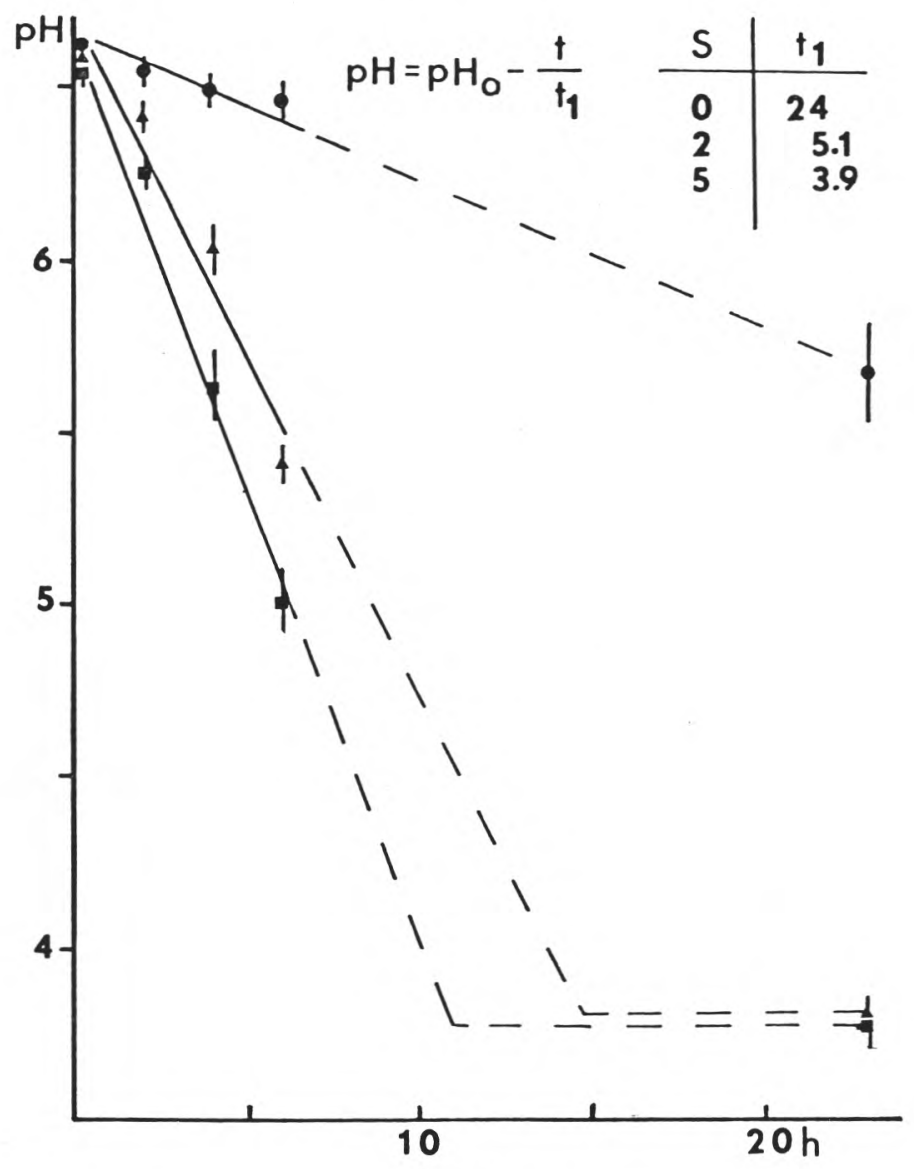

fig. 3

Effect of the quantity of $L$. acidophilus starter on the changes of $\mathrm{pH}$ during acidification of the milk retentate: $\bullet-0 \%, \mathbf{\Lambda}-2 \%,-5 \%$ starter added to the retentate. The average (points) and the standard deviation (vertical lines) were calculated for four series of experiments.

Influence de la quantité de levains de $\mathrm{L}$. acidophilus sur les modifications de $p H$ pendant l'acidification de rétentat de lait : $\bullet-0 \%$, A-2 \%, - $-5 \%$ de levain ajouté au rétentat. Les moyens (points) et l'écart-type (lignes verticales) étaient calculés pour quatre séries d'expériences.

milk and every 14 hours for whey retentate. When $2 \%$ or $5 \%$ of L.acidophilus starter was added the time of decreasing $\mathrm{pH}$ by one unit was much shorter, and a bit shorter for the whey than for 


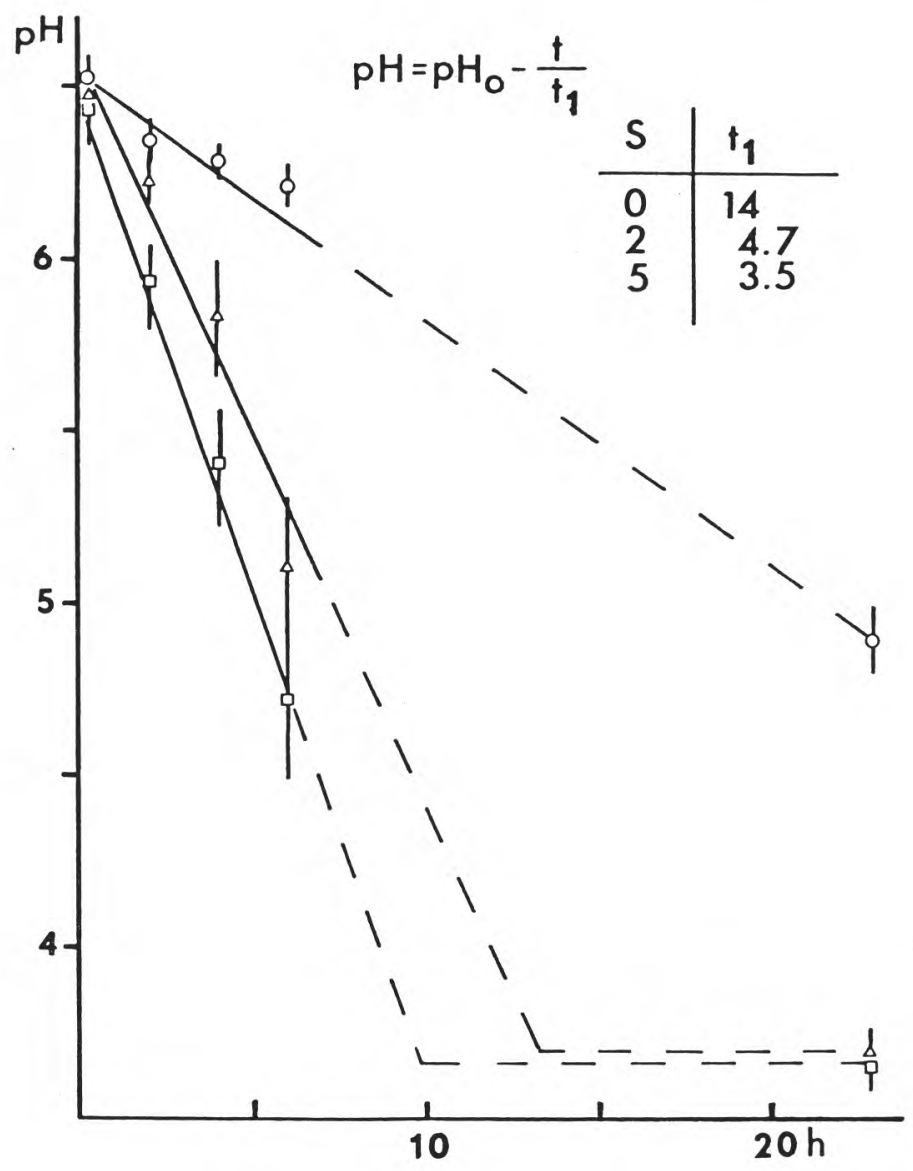

fig. 4

Effect of the quantity of $L$. acidophilus starter on the changes of $\mathrm{pH}$ during acidification of the whey retentate: $0-0 \%, \triangle-2 \%, \square-5 \%$ starter added to the retentate.

Influence de la quantité de levain de L. acidophilus sur les modifications de $p H$ pendant l'acidification de rétentat de lactosérum : ०-0\%, $\triangle-2 \%, \square-5 \%$ de levain ajouté au rétentat.

the milk retentate. This depended on buffer capacity which was greater for milk retentate because of higher protein concentration, but also on the environmental conditions of growing $L$. acidophilus. The final $\mathrm{pH}$ 3.5-3.7 mesured after 23 hours of acidification remained unchanged after 48 hours. 
There was linear correlation between the $\mathrm{pH}$ and the logarithm of lactic acid concentration (fig. 5) :

$$
\log \mathrm{C}=\log \mathrm{Co}-\mathrm{A} \cdot \mathrm{pH}(2)
$$

where : C : concentration of lactic acid ( $\% \mathrm{w} / \mathrm{w})$

Co : hypothetical concentration of lactic acid for $\mathrm{pH}=0$, calculated by the least squares method,

A : $\mathrm{pH}$ decrease, caused by ten-fold increase of lactic acid concentration, calculated by the least squares method.

For milk and whey retentates Co was respectively $85 \%$ and $71 \%$ and A was respectively equal 0.37 and 0.38 . Brulé and al., (1974) found that the quantity of lactic acid $\left(\mathrm{Q}_{\mathrm{L}}\right)$ to be added to the retentate to change the $\mathrm{pH}$ from 6.6 to 4.7 is expressed by the equation:

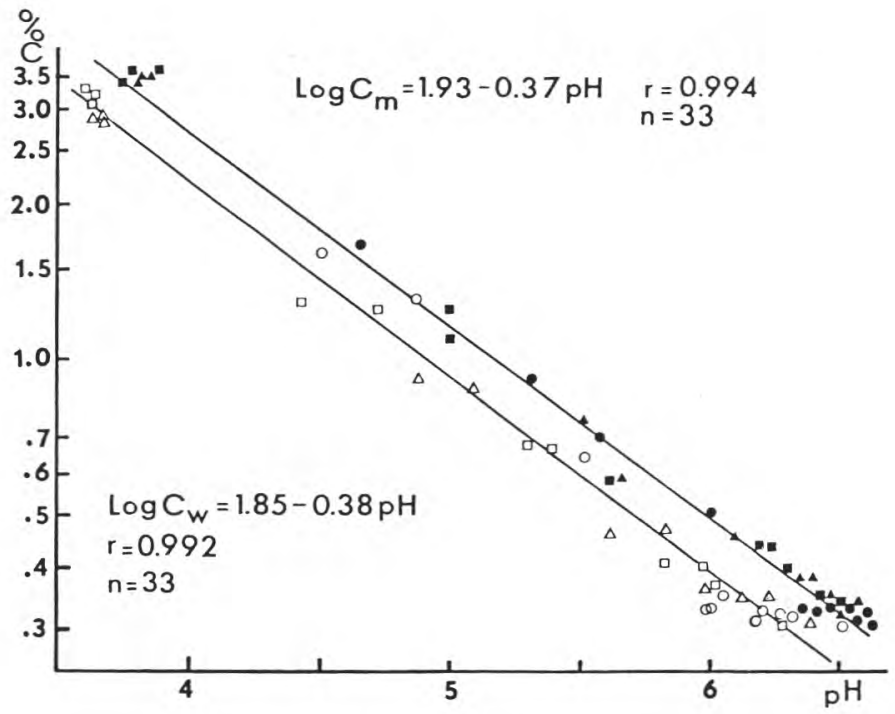

fig. 5

The correlation between the $\mathrm{pH}$ and the logarithm $(\mathrm{Log})$ of lactic acid concentration (\%) in milk retentate $(\mathrm{Cm})$ and whey retentate $(\mathrm{Cw}): \bullet-0 \%, \Delta-2 \%,-5 \%, 0-0 \%, \triangle-2 \%, \square-5 \%$ of $L$. acidophilus starter added to the milk retentate $(\bullet, \mathbf{\Delta}$, $\mathbf{m})$ or whey retentate $(0, \triangle, \square)$.

Corrélation entre le $\mathrm{pH}$ et le logarithme $(\mathrm{Log})$ de la concentration d'acide lactique dans le rétentat de lait $(\mathrm{Cm})$ et dans le rétentat de lactosérum $(\mathrm{Cw})$ : •-0 \%, $\mathbf{\Delta}-2 \%, \mathbf{-}-5 \%, 0-0 \%, \Delta-2 \%, \square-5 \%$ de levain de L. acidophilus ajouté au rétentat de lait $(\bullet, \mathbf{\Delta}, \mathbf{0})$ ou au rétentat de lactosérum $(0, \Delta, \square)$. 
$\begin{aligned} & \mathrm{Q}_{\mathrm{L}}=4.4 \mathrm{~F}+1.5(3) \\ \text { where }: & \mathrm{Q}_{\mathrm{L}}-\text { quantity (in grams) of lactic acid per } \mathrm{kg} \text { of retentate, } \\ & \mathrm{F}-\text { concentration factor of the retentate. }\end{aligned}$

As protein concentration factor in our experiments was on average 4.24 , this after recalculation according to equations (3) and (2) gives the value $A=0.34$. The results of Ehsani and al., (1982) recalculated by the equations (3) and (2) gives the value $A=0.34$ equal to that calculated from the results of Brulé and al. (1974).

The chemical composition of the retentates and quargs (fig. 6) is similar to that obtained by other authors (Maubois, Mocquot, 1971

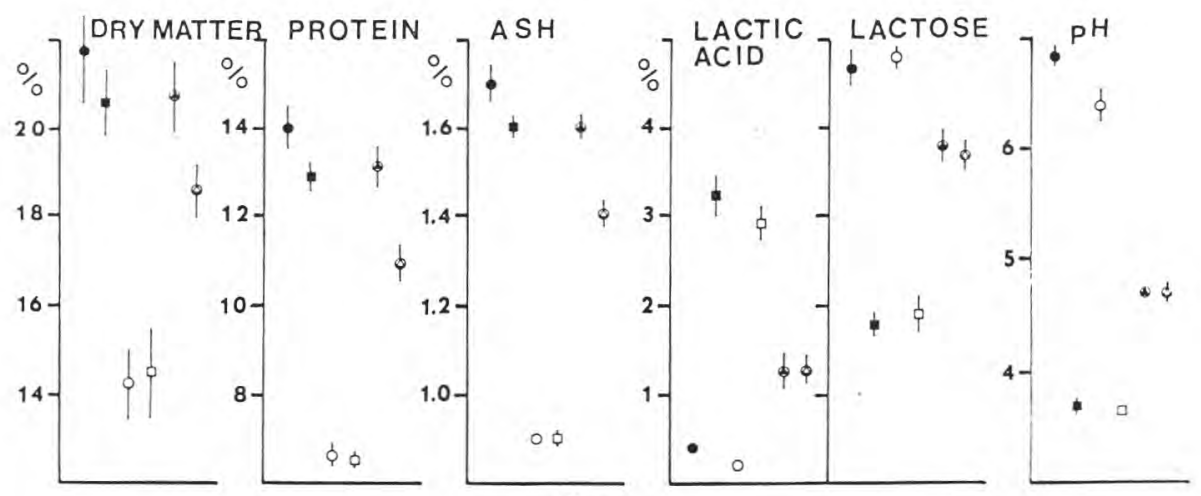

fig. 6

Chemical composition of: -milk retentate, -acidified milk retentate, O-whey retentate, $\square$-acidified whey retentate, $\$$-milk quarg, $\otimes$-whey proteins enriched quarg.

Composition chimique du : •-rétentat de lait, -rétentat acidifié de lait, O-rétentat de lactosérum, 口-rétentat acidifié de lactosérum, \$-quarg obtenu à partir de lait, (Q)-quarg enrichi en protéines de lactosérum.

Brulé and al., 1975; Puhan and Gallman, 1981; Grungerich, 1981 ; Winwood, 1983). The main difference in the chemical composition of UF quargs is higher ash content caused by higher retention of calcium (Maubois and Mocquot, 1971 ; Brulé and al., 1974 ; Puhan and Gallmann, 1981). From nutritional point of view this is an important advantage of MMV method. Higher calcium content is compensated by higher lactate concentration (Brulé and al., 1974, 1975; Puhan and Gallmann, 1981 ; Mahaut and al., 1982). The normal calcium concentration in the quarg type cheese is $0.125 \%$ while in 
the UF quarg 0.33-0.41\% (Brulé and al., 1974, 1975; Puhan and Gallmann, 1981 ; Mahaut and al., 1982 ; Winwood, 1983). On the molar basis, to compensate $0.2-0.3 \%$ of a dditional calcium, lactic acid concentration should be higher by $0.9-1.2 \%$. But practically, because most of the calcium is binded to phosphate and carboxylic groups of protein, additional lactate concentration in UF quarg is only $0.4 \%$ higher than in the traditional one (Brulé and al, 1975). It means that only $30-40 \%$ of additional calciums is in a free ionized form.

In the case of UF quarg obtained by MMV method described here, with acidified whey protein retentate used as an acidifying agent, the whey proteins to casein ratio was $1: 1.7$, while in the case of traditional quarg it is $1: 30$ to $1: 20$. From nutritional point of view, whey proteins are more valuable than casein, so they are used for preparation of so called humanized baby food. The quarg obtained by the method described above, could be called humanized too.

The amount of milk per $\mathrm{kg}$ of traditional quarg, containing $17,5 \%$ solids and $12.5 \%$ protein is of the level 4.5-4.6 1. When using MMV

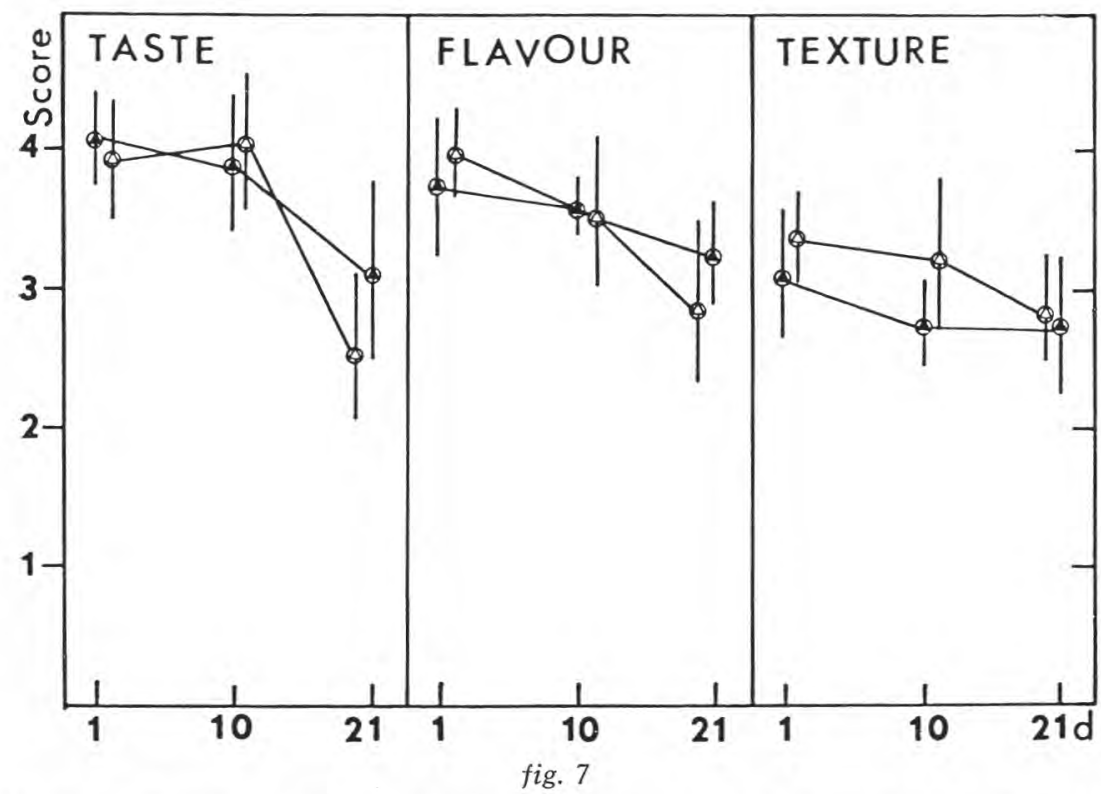

Changes of organoleptic quality of quargs during 21 days of storage at $10 \mathrm{C}$ : (4)-milk quarg, (D-whey proteins enriched quarg.

Changement de la qualité organoleptique des quargs pendant 21 jours de stockage à $10^{\circ} \mathrm{C}$ : (4-quarg à base de lait, (4)-quarg enrichi en protéines de lactosérum. 
ultrafiltration method the milk consumption is $3.2-3.8 \mathrm{l} / \mathrm{kg}$ of quarg (Friis, 1981; Gungerich, 1981). To obtain $1 \mathrm{~kg}$ of quarg of the same composition but with whey protein/casein ration equal $1: 1.7$ it is sufficient to use UF retentates from 2.91 of milk and 11-12 1 of whey.

Organoleptic quality of quargs obtained from milk or from milk and whey has been good for 10 days of storage at $10^{\circ} \mathrm{C}$, and no major differences were detected between the types of quargs (fig. 7). The texture was firmer for UF milk quargs than for normal ones, the reason of this could be the higher calcium content. After 21 days of storage at $10^{\circ} \mathrm{C}$, some bitterness and cheese like flavour were detected. This could be an effect of proteolysis and protein degradation products. Taking into account that industrially produced quarg in Poland by traditional method has only two days lasting keeping quality limit, caused mainly by the low quality of raw milk $\left(10^{7}\right.$ C.F.U. $\left./ \mathrm{ml}\right)$, the quarg obtained from the same milk by MMV method as described here had an exceptionaly good keeping quality, due to pasteurization of retentates before making the quarg. Low temperature pasteurization however does not destroy proteolytic and lipolytic enzymes, it concerns as well the rennet like microbial enzyme-fromase used for preparation of whey and other intracellular thermoresistant enzymes of Lactobacillus acidophilus origin for example. In this preliminary work we have not studied the extent of eventual proteolysis, as from practical point of view it did not seem to be important.

Microbiological quality of pasteurized retentates (fig. 8) and quargs was good. Whey retentates only were contamined with Coliform to the level $10 / \mathrm{ml}$, but after pasteurization of acidified retentates, neither Coliform nor Enterococci were detected in $0.1 \mathrm{ml}$ of retentates or quargs. As quargs were inoculated with $5 \%$ of butter starter to assure the necessary level of viable lactic acid bacteria, but also to develop better flavour, the initial number of viable microorganisms in quargs was $10^{7}-10^{8}$ and rose to $10^{9}-10^{10}$ in 21 days of storage at $10^{\circ} \mathrm{C}$. It indicates that lower temperature should be used, to prevent excessive proliferation of microorganisms, this would also improve the keeping quality. Yeasts and molds, from the initial number $10^{\circ} / \mathrm{ml}$ rose to $10^{1}-10^{3}$.

The results obtained in this work, as to the microbiological quality of UF quargs are similar to that obtained in our previous work (Korolczuk and al., 1983) with acid cheese type tvarog made from pasteurized milk and pasteurized over-acidified milk. If compared to the microbiological quality of ordinary, industrially produced quargs (Maleszewski and al., 1976; Burzynska, 1980 ; Feder, 1981; Maciejska-Roczan and Burzynska, 1981) the quality obtained in this work shows the potential advantages of proposed pasteurization of acidified retentates before making quarg by MMV method. 


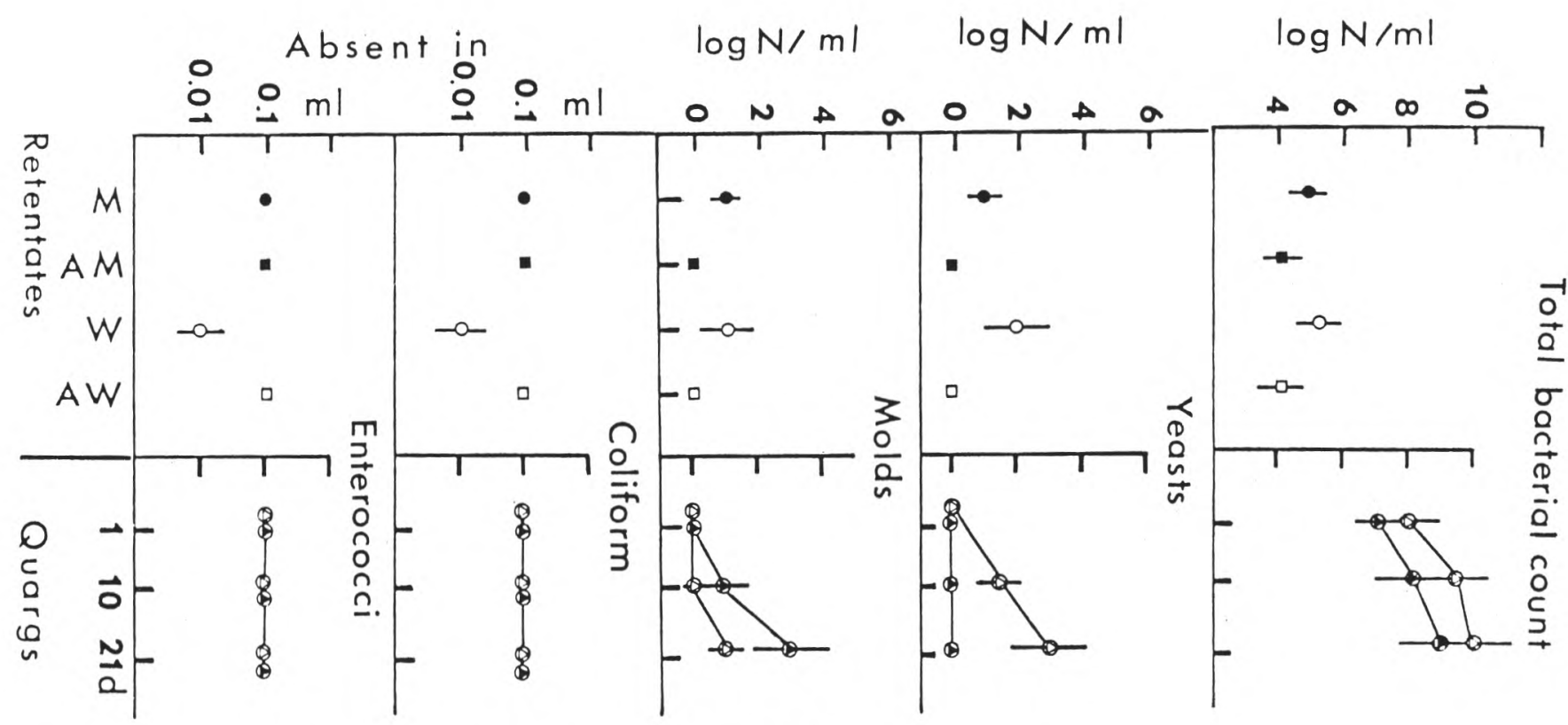

fig. 8

Microbiological quality of retentates and quargs: •-milk-retentate, whey retentate, $\$$-milk quarg, Q-whey proteins enriched quarg.

Qualité microbiologique des rétentats et des quargs : •-rétentat de lait, -rétentat acidifié de lait, o-rétentat de lactosérum, -rétentat acidifié de lactosérum, \-quarg à base de lait, \-quarg enrichi en protéines de lactosérum. 
Of course, it has to be stressed that this work was carried out on the laboratory scale. When scaling up, special precautions has to be taken as to the reinfection problems after pasteurization of the retentates.

From technological point of view, though we could not reach the $\mathrm{pH}$ level below 3.5 for the retentates, what was easily accessible for the milk, but the low temperature long time $\left(65^{\circ} \mathrm{C}, 20 \mathrm{~min}\right)$ pasteurization did not give any visible effects of protein coagulation, but at high concentration of protein, it is difficult to judge, if there were any changes. The viscosity of the retentate was too high to pass it through the plate heat exchanger.

We observed a gelification of whey protein retentate, while heating at $65^{\circ} \mathrm{C}$ and even at $55^{\circ} \mathrm{C}$. This needs to be quantified, but from technological point of view it improves the water holding capacity and probably prevents or decreases the expulsion of whey during storage of quarg.

\section{Bibliographie}

AktieselKabet de Danske sukKerfabrikKer (1974). - Procédé de fabrication du fromage. Brevet français $\mathrm{n}^{\circ} 2222019$.

A.O.A.C. (1975). - Official Methods of Analysis of the Association of Official Analytical Chemist. Ed. W. Hornits. A.O.A.C. Washington, p. 256, $282-4$.

Brulé (G.), Maubois (J. L.), Fauquant (J.). (1974). - Etude de la teneur en éléments minéraux des produits obtenus lors de l'ultrafiltration du lait sur membrane. Le Lait, 539-540, 600-615.

Brulé (G.), Maubois (J. L.), Vandeweghe (J.), Fauquant (J.), Goudedranche (H.) (1975). - Utilisation de l'ultrafiltration sur membrane pour la fabrication de fromages du type pâtes fraîches. Revue Laitière Française, 328, 117-122.

BURZYNSKA (H.) (1980). - Ocena higieniczna cyklu produkcyjnego serkow homogenizowanych. Roczniki Panistwowego Zakladu Higieny, 31 (3), 243-251.

DANIEWSKI (P.) (1973). - Wplyw parametrow procesowych na konsystencje twarogu chudego. Roczniki Instytutu Przemyslu Mleczarskiego, 15 (2), 107-115.

Dolle (E.) (1981). - Erkenntinisse über das Westfalia-Thermo-Speisquark Verfaren. Molkerei-Zeitung Welt der Milch, 35 (20), 628-629, 632-633.

Ehsani (R.), Bennasar (M.) ToRodo de la Fuente (B.) (1982). - Aptitude à la coagulation de poudres de lait préacidifiées à $0^{\circ} \mathrm{C}$. Le Lait, 62, 276-300.

FEDER (H.) (1981). - Zum Keimprofil des Sauermilchkäses und des Ausgangsproduktes Sauermilchquark. Deutsche Tierärztliche Wochenschrift, 88 (1), 30-31.

FIL-IDF (1971 a). - Laits fermentés : dénombrement des coliformes. Norme $\mathrm{n}^{\circ} 65$.

FIL-IDF (1971 b). - Laits fermentés : dénombrement des organismes microbiens de contamination. Norme $\mathrm{n}^{\circ} 66$.

FIL-IDF (1974 a). - Détermination de la teneur en lactose du lait. Norme $\mathrm{n}^{\circ} 28 \mathrm{~A}$.

FIL-IDF (1974 b). - Lait et produits laitiers : dénombrement des bactéries coliformes. Normes $n^{\circ} 73$.

FIL-IDF (1980). - Lait et produits laitiers : levures et moisissures. Norme $\mathrm{n}^{\circ} 94$.

FIL-IDF (1981 a). - Examen sensoriel du lait et des produits laitiers. Norme $\mathrm{n}^{\circ} 99$.

FIL-IDF (1981 b). - Statistiques de consommation pour le lait et les produits laitiers. Bulletin, document 160 .

FRIIS (T.) (1981). - Production of quarg by membrane filtration. North European Dairy Journal, 47 (6), 165-170. 
GUNGERICH (C.) (1981). - Production of quarg by ultrafiltration. North European Dairy Journal, 47 (7), 212-217.

KNUPFER (H.) (1982). - Quarkausbeute-Ultrafiltration. Molkerei. Zeitung Welt der Milch, 36 (19), 559-562.

Korolczuk (J.), PaWlowska (D.), Daniewski (M.) (1971). - Wplyw sposobow koagulacji na poziom pozostatosci frakcji bialkowych w serwatce, Roczniki Instytutu Przemyslu Mleczarskiego, 13 (3), 53-59.

KorolczuK (J.), Kunachowicz (H.), Daniewski (P.), Secomska (B.) (1975). - Wplyw obrobki termicznej mleka na wartosc odzywczca twarogu. Roczniki Instytutu Przemyslu Mleczarskiego, 17 (1), 45-53.

KorolczuK (J.), GRzelaK (D.), ZMarlicki (S.), Janicki (A.) (1983). - New approach to acid curd cheese technology. New Zealand Journal of Dairy Science and Technology, 18, 101-107.

Kroger (M.) (1980). - The manufacture of quarg cheese. Cultured Dairy Products Journal, 15 (3), 11-14.

Maciejska-Roczan (K.), Burzynska (H.) (1981), - Wystepowanie roznych gatunkow bakterii z rodziny Enterobacteriaceae w wybranych produktach mleczarskich. Roczniki Panstwowego Zakladu Higieny, 32 (2), 107-112.

Mahaut (M.), Maubors (J. L.), Zink (A.) (1982), - Eléments de fabrication de fromages frais par ultrafiltration sur membrane de coagulum de lait. $L a$ Technique Laitière, 961, 9-13.

Maleszewski (J.), Bachryj (F.), BaWlik (I.), Borowiak (M.), CZarnowska (W.), Chybowski (J.), Dziurowik (Z.), Frasunkiewicz (B.), Glowacki (M.), JedrzeJowsKa (H.), Klos (J.), Koc (T.), KRZEMinska (B.), Lewicka (J.), Lichocinska (H.), Maciszek (A.), SMykal (B.), Wilczynska-Stelmach (B.) (1976). - Wystspowanie mikroorganizmow patogennych w twarogu. Roczniki Panstwowego Zaktadu Higieny, 27 (2), 147-151.

MANN (E. J.) (1982 a). - Ultrafiltration of milk for cheese making.Dairy Industries International, 47 (12), 11-12.

MANN (E. J.). - (1982 b). - Fromages frais. Quarg. Revue Laitière Française, 413, 101-102.

Maubors (J. L.), Brulé (G.) (1982). - Utilisation des techniques à membrane pour la séparation, la purification et la fragmentation des protéines laitières. Le Lait, 62, 484-510.

Maubois (J. L.) Mahaut (M.) (1974). - Application de l'ultrafiltration sur membrane dans l'industrie fromagère. Revue Laitière Française, 322, 479-484.

Maubots (J. L.), Mocovot (G.) (1971). - Préparation de fromage à partir de " préfromage liquide " obtenu par ultrafiltration du lait. Le Lait, 508, 495-533.

Maubois (J. L.), Mocouot (G.), Vassal (L.) (1969). - Procédé de traitement du lait et des sous-produits laitiers. Brevet français $\mathrm{n}^{\circ} 2052121$.

Moldovan (E.), Toma (A.), Donescu (E.) (1982). - Some information on ultrafiltrated milk utilization in quarg production. In XXI International Dairy Congress, Vol. I, Book 2, 461-462.

Puhan (Z.), GallmanN (P.) (1981). - Ultrafiltration in the manufacture of quarg. North European Dairy Journal, 47 (1), 4-5.

SNOEREN (T. H. M.) (1980). - Die Anwendung und Wirkung von Hydrokolloiden in Milchprodukten. In Gelier und Verdickungsmittel in Lebensmitteln. Ed. by Neukom (H. J.), Pilnik (W.), Zurich, Forster Verlag A.G., 263-274.

Stenne (P.) (1973). - Procédé de fabrication d'aliments protéiques, notamment de fromages. Brevet français $\mathrm{n}^{\circ} 2232999$.

SteNNe (P.) (1976). - Procedé de fabrication de fromages. Brevet français $\mathrm{n}^{\circ}$ 2340052.

Strmiska (J.) (1980). - Vyroba termo-tvarohu a tvarohovych pen. Prumysl Potravin, 31 (2), 94-96.

WiNwOOD (J.) (1983). - Quarg production methods-past, present and future. Journal of the Society of Dairy Technology, 36 (4), 107-109. 